\title{
Variation in the Proximate, Energy and Mineral Compositions of Different Body Parts of Macrobrachium macrobranchion (Prawn)
}

\author{
E. Ekpenyong ${ }^{1}$, I. O. Williams ${ }^{2} \&$ U. U. Osakpa ${ }^{1}$ \\ ${ }^{1}$ Department of Zoology and Environmental Biology, University of Calabar, Calabar, Nigeria \\ ${ }^{2}$ Department of Biochemistry, University of Calabar, Calabar, Nigeria \\ Correspondence: I. O. Williams, Department of Biochemistry, Faculty of Basic Medical Sciences, University of \\ Calabar, PMB 1115, Calabar, Nigeria. Tel: 234-803-501-8175. E-mail: imawills@yahoo.com
}

\author{
Received: February 5, 2013 Accepted: March 22, 2013 Online Published: March 28, 2013 \\ doi:10.5539/jfr.v2n2p150 URL: http://dx.doi.org/10.5539/jfr.v2n2p150
}

\begin{abstract}
The proximate and elemental compositions of various body parts of Macrobrachium macrobranchion (prawn) obtained from the Great Kwa River, a major tributary of Cross River estuary in Cross River State, Nigeria were investigated using standard methods of AOAC. Results showed that the flesh had significantly higher $(\mathrm{p}<0.05)$ levels of protein, fat and moisture $(22.32,7.70$ and $58.40 \%$, respectively) than the other body parts analyzed. Equally high in protein were the head $(20.11 \%)$ and appendages $(19.28 \%)$, while the exoskeleton recorded the least protein content $(14.02 \%)$. The flesh had the least $(\mathrm{p}<0.05)$ crude fibre $(0.03 \%)$ and carbohydrate $(7.22 \%)$ contents, and conversely had the least energy value $(187.50 \mathrm{kcal} / \mathrm{g})$ among the body parts. Ash content was significantly higher $(\mathrm{p}<0.05)$ in the exoskeleton $(7.14 \%)$, the appendages $(7.01 \%)$ and the head $(6.05 \%)$ than in the flesh (4.30\%). Individual elements were also unequally distributed among the four body parts investigated: sodium and potassium were more concentrated in the flesh $(189.27 \mathrm{mg} / 100 \mathrm{~g}$ and $114.70 \mathrm{mg} / 100 \mathrm{~g}$, respectively), while calcium and magnesium were highest in the appendages $(99.02 \mathrm{mg} / 100 \mathrm{~g}$ and $171.40 \mathrm{mg} / 100 \mathrm{~g}$, respectively). The concentration of iron was generally low among the body parts; however, it was highest ( $\mathrm{p}<$ 0.05 ) in the head. The usual practice of retaining the flesh and discarding the "hard" parts (head, exoskeleton and appendages) of prawn during food preparation should be discouraged as this may promote wastage of important nutrients.
\end{abstract}

Keywords: Macrobrachium macrobranchion, prawn, proximate composition, energy, mineral, body parts

\section{Introduction}

The high prevalence of diet-related chronic diseases in developed and developing countries of the world has led to increased public awareness and interest in human nutrition. It has now become popular for consumers to actively select foods for health maintenance and disease prevention. The current wave of scientific literature which links diet with the incidence of certain diseases has brought seafood to the attention of the health-conscious public. Epidemiological studies have shown that those cultures that predominantly consume seafood have low incidence of heart attacks (Hu et al., 2002; Willett, 2007). According to the Institute of Medicine (IOM, 2006) report, seafood is nutrient-rich and provides high quality protein that is low in saturated fat and rich in polyunsaturated fats especially the omega-3 fatty acids eicosapentaenoic acid (EPA) and docosahexaenoic acid (DHA). Regular consumption of seafood has been linked to health benefits for the general population.

Prawns are a group of popular sea foods found worldwide. They are physically similar and very closely related to shrimps, belonging to the same order Decapoda of the class Crustacea and only distinguishable in their gill structure. In markets and restaurants the two words (shrimps/ prawns) are used interchangeably. Prawns serve a number of economic purposes including source of food, foreign exchange, income and provision of employment (Akegbejo-Samson, 1997). Prawns are highly relished, and amongst the leading priced sea foods on the global menu. Prawn has been reported to be the most important internationally traded fishery commodity in terms of value (Gillett, 2008). In many tropical developing countries including Nigeria, prawn is the most valuable fishery export, while the employment aspect is also significant (Areola, 2007; Gillett, 2008). The global market for prawns is ever on the increase largely due to high rate of consumption in the US, Europe and Japan (US 
Trade Representative, 2005; Zabbey, Erondu, \& Hart, 2010). In Nigeria, the demand for prawns far outstrips its supply (Sogbesan, Olowosegun, \& Ibiyo, 2005; Areola, 2007).

In the diet, prawns supply good quality proteins, vitamins A and D, and several dietary minerals especially calcium and iron (Abulude, Lawal, Ehikhamen, Adesanya, \& Ashafa, 2006). When consumed whole, they also supply appreciable quantities of dietary fibre, which is low or undetectable in the flesh (Adeyeye \& Adubiaro, 2004). Studies by Ravichandran, Ramesh Kumar, and Prince (2009) revealed that prawns are extremely low in fat and calories, making them a very healthy choice of food. Apart from its low fat content, prawns serve as a major source of omega-3 fatty acids which lower the total serum cholesterol levels (Stansby, 1982), and also prevent heart diseases and a number of circulatory problems. On account of the very low animal protein intake by Nigerians due primarily to the decrease in per capita production, prawns have become a major source of animal protein especially for the low income earners because of its low price and availability (Adeyeye, 1996). According to Oladimeji and Sadiku (1991), prawns are among the cheapest sources of animal protein and account for about $40 \%$ of the total animal protein intake of the average Nigerian.

Like other crustaceans such as crayfish, crabs and lobsters, prawns are rich in chitin a structural polysaccharide that has proven useful for several medical and industrial purposes (Park \& Kim, 2010; P. Morganti, G. Morganti, $\&$ A. Morganti, 2011). A number of studies have shown that the crustacean shells are the most important source of chitin for commercial use due to its high content and ready availability (Gagné \& Simpson, 1993; Subasinghe, 1999; Wang \& Xing, 2007; Morganti et al., 2011; W. Arabia, L. Arabia, Adour, \& Amrane, 2012).

In Nigeria as well as many other parts of the world, prawn consumers seem to be more interested in the consumption of the fleshy parts of the shell fish, while the hard parts are often discarded. Thus, preparing prawns for consumption usually involves removing the hard parts such as the head, shell or exoskeleton, carapace and tail (Zhai \& Hawkins, 2002; Gimeno et al., 2007). This study sought to investigate the desirability or otherwise, of the continuous exclusion of these hard parts from human diets. Hence, we examined the proximate composition and mineral content of the different body parts of prawn (Macrobrachium macrobranchion).

\section{Materials and Methods}

\subsection{Sample Collection and Preparation for Analyses}

The fresh prawn (M. macrobranchion) samples used in this study were purchased at Obufa Esuk beach market from fishermen who caught them in the Great Kwa River, a major tributary of Cross River Estuary in February 2010. The samples were immediately conveyed to the research laboratory in the department of Zoology and Environmental Biology, University of Calabar. The samples were carefully washed with tap water after which they were thoroughly rinsed with distilled water. The different body parts namely, the head region (A), appendages (B), exoskeleton with carapace (C) and the flesh (D), were separately removed. A portion of each fresh part was taken out for moisture determination while the other part was dried in an electric oven at between $55^{\circ} \mathrm{C}$ and $60^{\circ} \mathrm{C}$ to a constant weight and allowed to cool. It was then ground to fine powder using a standard mill, kept in an airtight sample bottle with thorough identification and stored in the refrigerator at $-20^{\circ} \mathrm{C}$ pending analysis.

\subsection{Proximate Analysis}

The levels of protein, fat, moisture and ash (proximate composition) in the head, appendages, exoskeleton (with carapace), and the flesh were determined by the methods of Association of Official Analytical Chemists (AOAC, 2005). For moisture content, $2 \mathrm{~g}$ of each fresh body part was dried to a constant weight at $87-98^{\circ} \mathrm{C}$ with the aid of an electric oven (Astell Heason, England) for 24 hours. Moisture content was taken as the weight loss at the end of the drying period. Protein was determined by the micro-Kjeldahl method which estimated the amount of nitrogen in the sample and subsequently multiplied by a factor of 6.25 . Fat content was obtained by intermittent extraction with petroleum ether (B. P. $40-60^{\circ} \mathrm{C}$ ) using Soxhlet apparatus (Corning, England). Ash was determined from the residue left after incineration of a weighed portion of the sample at $550^{\circ} \mathrm{C}$ using a muffle furnace. Crude fibre was estimated by boiling the sample with $1.25 \%(\mathrm{w} / \mathrm{v})$ sulphuric acid and then with $1.25 \%$ $(\mathrm{w} / \mathrm{v})$ sodium hydroxide and incinerating the residue at $550^{\circ} \mathrm{C}$; the loss in weight represented the crude fibre content of the sample (AOAC, 2005). Carbohydrate content was obtained by difference after subtracting the moisture, protein, fat and ash from the total dry matter, expressed in percentage.

\subsection{Determination of Energy Value}

The caloric value, expressed as $\mathrm{kcal} / \mathrm{g}$ of each body part was calculated using the Atwater factors for protein, fat, and carbohydrate (Atwater \& Bryant, 1900). Accordingly, the amount of protein obtained by chemical analysis 
was multiplied by 4 , fat was multiplied by 9 , and digestible carbohydrate was multiplied by 4 . Energy was calculated as the sum of the three values. That is, Energy $=[$ protein $(x 4)+$ fat $(x 9)+$ carbohydrate $(x 4)] \mathrm{kcal} / \mathrm{g}$.

\subsection{Determination of Mineral Elements}

Elemental composition was analysed using the solution obtained by dry-ashing the samples at $550^{\circ} \mathrm{C}$ and dissolving in distilled water with a few drops of concentrated hydrochloric acid in a volumetric flask. Sodium (Na) and potassium (K) were measured with a Corning U.K. Model 405 flame photometer (AOAC, 1990) while iron $(\mathrm{Fe})$, magnesium $(\mathrm{Mg})$ and calcium $(\mathrm{Ca})$ were obtained spectrophotometrically (AOAC, 1990).

\subsection{Statistical Analysis}

All results were submitted to one-way analysis of variance (ANOVA) using the statistical package for social sciences (SPSS) 2009 (version 17.0).

\section{Results}

\subsection{Proximate Composition}

Data obtained on the proximate analysis of the different body parts are as shown in Figure 1. The moisture content ranged from $33.04 \%$ in the exoskeleton to $58.40 \%$ in the flesh. Similarly, the highest protein content $(22.32 \%)$ occurred in the flesh while exoskeleton had the least $(14.02 \%)$; protein content of the head and appendages was comparable $(20.11 \%$ and $19.28 \%$, respectively). Again, fat content was highest $(7.70 \%)$ in the flesh and least (4.04\%) in the exoskeleton. However, the flesh recorded the least ash content $(4.30 \%)$ while the exoskeleton had the highest (7.14\%), closely followed by the appendages $(7.01 \%)$. Crude fibre and carbohydrate contents were also least in the flesh $(0.03 \%$ and $7.22 \%$, respectively) but highest in the exoskeleton $(7.20 \%$ and $34.51 \%$, respectively).

\subsection{Energy Value}

Figure 2 shows the energy value of the various body parts. Energy was generally fairly distributed among the four body parts, the highest occurring in the exoskeleton $(230 \mathrm{kcal} / \mathrm{g})$.

\subsection{Mineral Composition}

The results of the elemental composition are shown in Figure 3. Sodium and potassium were highest $(\mathrm{p}<0.05)$ in the flesh, which also recorded low iron and calcium contents $(4.83 \pm 0.02 \mathrm{mg} / 100 \mathrm{~g}$ and $61.02 \pm 0.03 \mathrm{mg} / 100$ $\mathrm{g}$, respectively). The appendages had the highest calcium $(99.02 \pm 0.03 \mathrm{mg} / 100 \mathrm{~g})$ and magnesium $(171.40 \pm$ $0.20 \mathrm{mg} / 100 \mathrm{~g}$ ) contents.

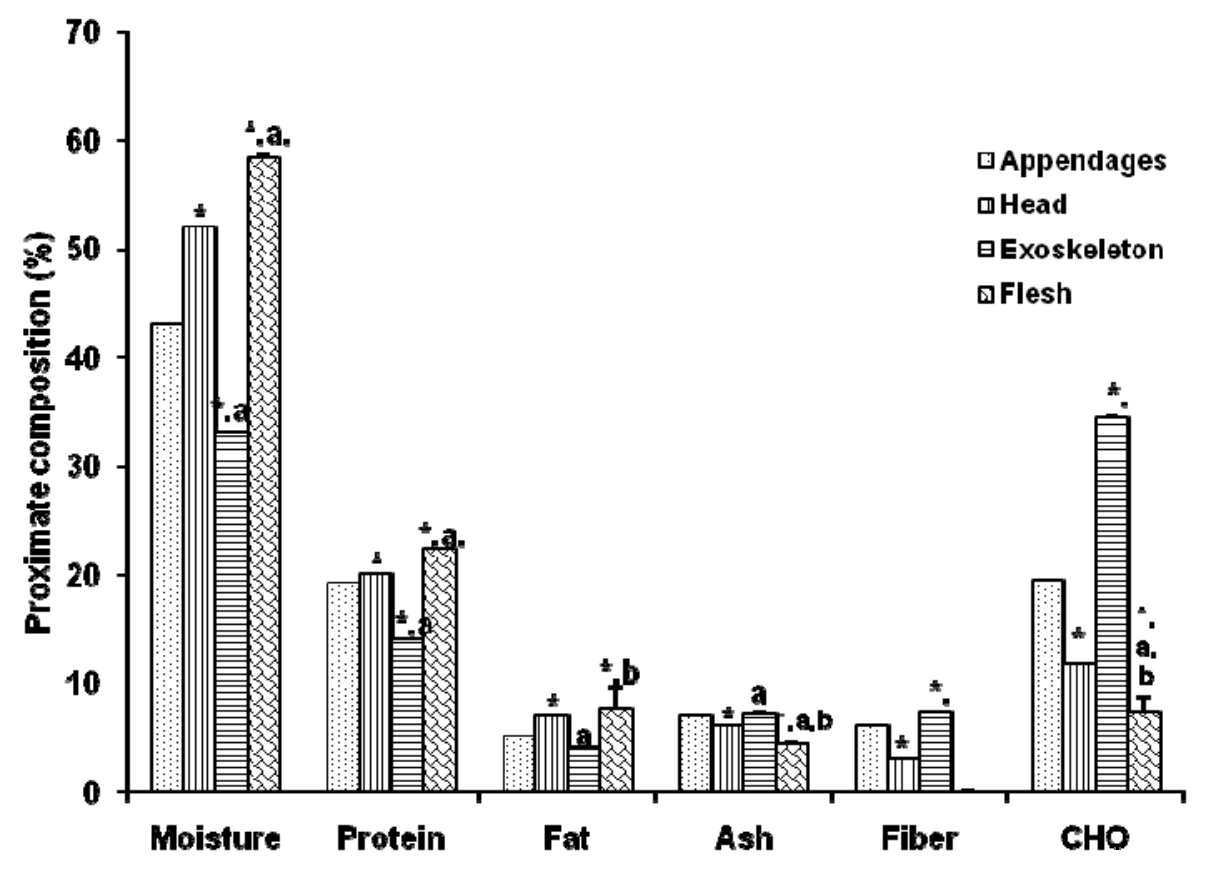

Figure 1. Proximate composition of the different body parts of M. macrobranchion Values are mean $\pm \mathrm{SD}, \mathrm{n}=3 ; \mathrm{P}<0.05$ vs App., $\mathrm{a}=\mathrm{P}<0.05$ vs head; $\mathrm{b}=\mathrm{P}<0.05$ vs exos. 


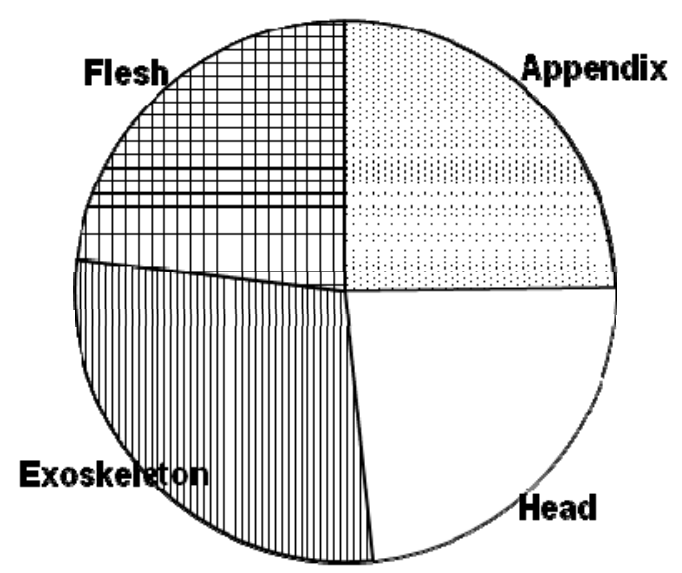

Figure 2. Energy values of the different body parts of M. macrobranchion

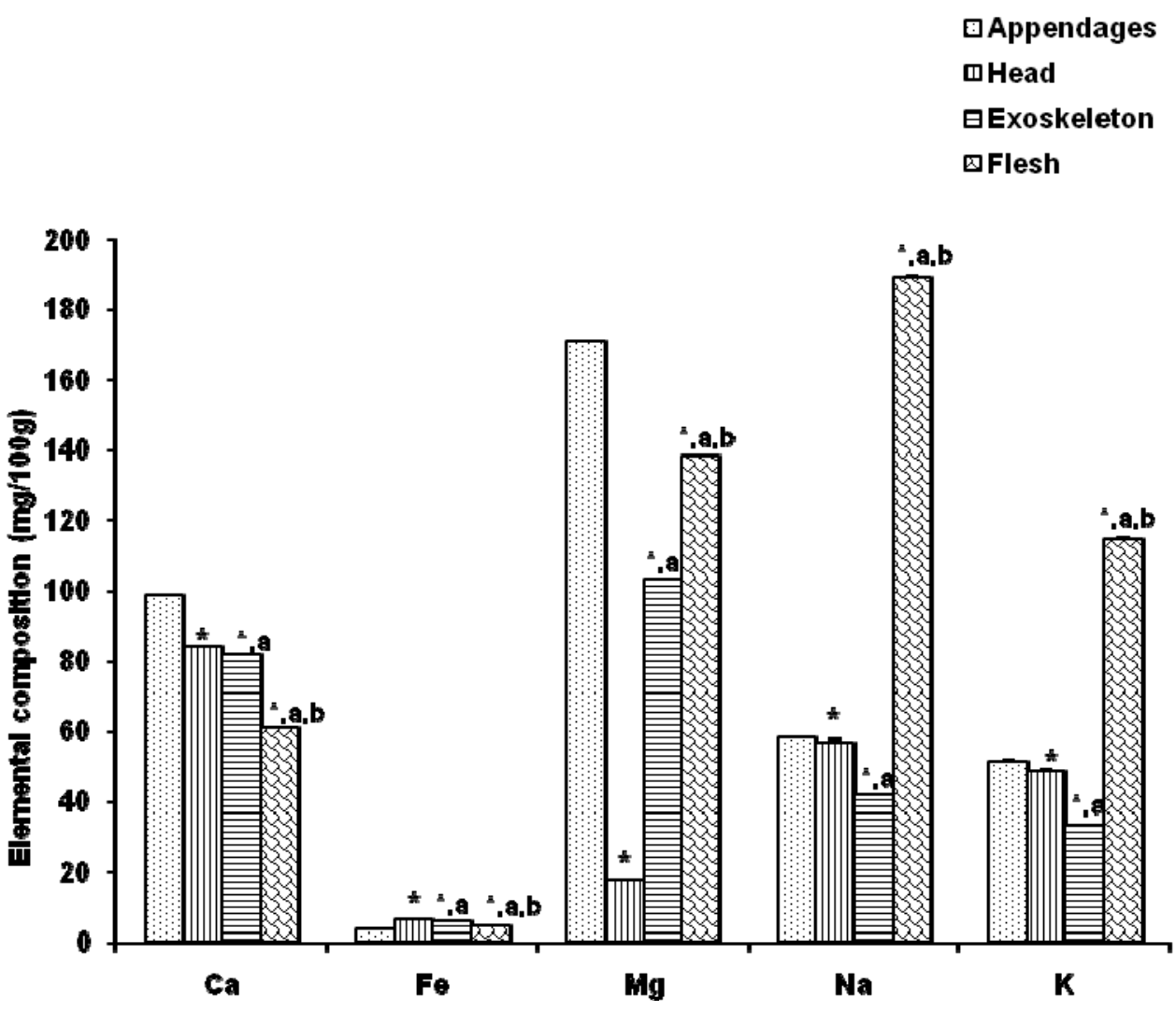

Figure 3. Elemental composition of the different body parts of $M$. macrobranchion

Values are mean $\pm \mathrm{SD}, \mathrm{n}=3$; ${ }^{*} \mathrm{P}<0.05$ vs App., $\mathrm{a}=\mathrm{P}<0.05$ vs head; $\mathrm{b}=\mathrm{P}<0.05$ vs exos.

\section{Discussion}

Crustaceans are generally known to constitute important nutritional components in the average diets of a vast population in both developing and developed societies, particularly where higher animal proteins are either unaffordable or unavailable (Fasakin, Bello-Olusoji, \& Oyekanmi, 2000). According to Abulude et al. (2006), the prawn is valuable in the diet because it provides good quality protein, vitamins $\mathrm{A}$ and $\mathrm{D}$, as well as several important dietary minerals especially calcium and iron. However, literature reports indicate that the biochemical/ nutrient composition of any organism may vary with the parts of the animal, season, size and stage of maturity, and the chemical nature of its habitat (Soundarapandian \& Ananthan, 2008; Dinakaran \& Soundarapandian, 2009; Ehigiator \& Nwangwu, 2011). 
The results of this study show that the head, appendages, exoskeleton are as rich as the flesh in terms of proximate and mineral compositions. However, the carbohydrate content and calorie value of the exoskeleton was observed to be higher than the contents recorded for the flesh. On the contrary, the moisture and protein contents of the flesh, head and appendages were comparatively higher $(\mathrm{p}<0.05)$ than in the exoskeleton. This observation disagrees with report of Ravichandran et al. (2009) for Indian white shrimp Penaeus indicus, but agrees with the results of the work reported by Ehigiator and Nwangwu (2011) for two prawn species $M$. vollenhovenii and M. macrobranchion. Also, the crude fibre content of the flesh was observed to be very low, compared to the exoskeleton, and the appendages. The low flesh crude fibre content is consistent with the report of Ehigiator and Nwangwu (2011), but contrasts with the report of Ravichandran et al. (2009). The higher carbohydrate content and calorie value of the exoskeleton may be attributed to the presence of chitin, a linear polymer of acetyl D-glucosamine with similar properties to cellulose (Morganti et al., 2011).

A high protein level is also observed for the head, appendages and fleshy portion of the prawn, compared to the exoskeleton. The level of protein obtained in this study is higher than that reported by Fasakin et al. (2000) for $M$. vollenhovemi. However, the protein content of the different body parts of the prawn recorded here is relatively lower than that reported by Ehigiator and Nwangwu (2011) for the whole body, the flesh and the exoskeleton of freshwater prawn, and by Ravichandran et al. (2009) for P. indicus. Dinakaran and Soundarapandian (2009) reported that protein is one of the most prominent biochemical components of crustaceans and its quantity in this class of organisms is largely influenced by the extent of fat and water contents, stage of maturity and sex of the organism. Some earlier publications reported inverse relationship between lipids and protein (Pillay \& Nair, 1973; Sriraman, 1978; Radhakrishnan, 1979). Pillay and Nair (1973) also found an inverse relationship between lipids and moisture content. Our study did not observe this kind of relationship rather both fat and moisture was highest in the flesh which also recorded the highest level of protein.

The results of our study also show that mineral elements are disproportionately distributed to different parts of the prawn. While calcium content of the head, appendages and exoskeleton is observed to be higher than that of the flesh, the sodium and potassium contents of the flesh are higher than those of the other parts. Iron content was also lower in the flesh than most of the other body parts.

\section{Conclusion}

Results of the present study have shown varying concentrations of essential nutrients in the different body parts of M. macrobranchion. For instance, calcium is more concentrated in the hard body parts than the flesh, while iron is also obtained in appreciable quantities in all the body parts. From the results, all the body parts of $M$. macrobranchion contain essential nutrients required for proper functioning of the human/ animal body. For maximum utilization of these nutrients, it is suggested that all body parts of the prawn should be blended together and used in food preparation/ formulation.

\section{References}

Abulude, F. O., Lawal, L. O., Ehikhamen, G., Adesanya, W. O., \& Ashafa, S. L. (2006). Distribution of macrominerals in four prawns from the coastal area of Ondo State, Nigeria. Journal of Fisheries International, 1(2-4), 70-72.

Adeyeye, E. L. (1996). Waste yield, proximate and mineral composition of three different types of land snails found in Nigeria. International Journal of Food Sciences and Nutrition, 47(2), 111-116. http://dx.doi.org/10.3109/09637489609012572

Adeyeye, E., \& Adubiaro, H. (2004). Chemical composition of shell and flesh of three prawn samples from Lagos Lagoon. A Journal of the Science of food and Agriculture, 84(5), 411-414. http://dx.doi.org/10.1002/jsfa.1649

Akegbejo-Samson, Y. (1997). Introduction to aquaculture fisheries management in Nigeria (pp. 9-15). Natural Resources Series 2. Abeokuta, Nigeria: Goal Educational Publishers.

AOAC. (1990). Association of Official Analytical Chemists. Official method of analysis (15th ed.). Washington, DC., USA.

AOAC. (2005). Association of Official Analytical Chemists. Official methods of analysis (18th ed.). Arlington V. A., USA.

Arabia, W., Arabia, L., Adour, L., \& Amrane, A. (2012). Chitin extraction from crustacean shells by biological methods: A review. Manuscript submitted for publication. 
Areola, F. O. (2007). Fish marketing and export potentials of fish and fisheries products in Nigeria. Paper presented at the Educative and Informative Aqua-cultural Workshop and Exhibitions tagged: sustainable fisheries livelihood: management and food security in Nigeria, (February 23, 2007), Lagos.

Atwater, W. O., \& Bryant, A. P. (1900). The availability and fuel value of food materials (pp. 73-110). Washington, DC: US Government Printing Office, Agriculture Experiment Station 12th Annual Report.

Dinakaran, G. K., \& Soundarapandian, P. (2009). Biochemical status of edible Palaemonid prawn Macrobrachium idella idella. Advanced Journal of Food Science and Technology, 1(1), 19-26.

Ehigiator, F. A. R., \& Nwangwu, I. M. (2011). Comparative studies of the proximate composition of three body parts of two freshwater prawns' species from Ovia River, Edo State, Nigeria. Australian Journal of Basic and Applied Sciences, 5(12), 2899-2903.

Fasakin, E. A., Bello-Olusoji, O. A., \& Oyekanmi, F. B. (2000). Nutritional value of flesh and water composition of some processed important crustaceans in Nigeria. Applied Tropical Agriculture, 5(2), 148-153.

Gagné, N., \& Simpson, B. K. (1993). Use of proteolytic enzymes to facilitate the recovery of chitin from shrimp wastes. Food Biotechnology, 7, 253-263.

Gillett, R. (2008). Global study of shrimp fisheries. FAO Fisheries Technical Paper 475. FAO, Rome, p. 331.

Gimeno, M., Ramirez-Hernandez, J. Y., Mártinez-Ibarra, C., Pacheco, N., Garcia-Arrazola, R., Barzana, E., \& Shirai, K. (2007). One-solvent extraction of astaxanthin from lactic acid fermented shrimp wastes. Journal of Agricultural and Food Chemistry, 55, 10345-10350. http://dx.doi.org/10.1021/jf071469h

Hu, F. B., Bronner, L., Willett, W. C., Stampfer, M. J., Rexrode, K. M., Albert, C. M., ... Manson, J. E. (2002). Fish and omega-3 fatty acid intake and risk of coronary heart disease in women. The Journal of the American Medical Association, 287(14), 1815-1821. http://dx.doi.org/10.1001/jama.287.14.1815

IOM. (2006). Institute of Medicine. Seafood choices: Balancing benefits and risks. National Academies Press, Washington, DC 20055, USA.

Morganti, P., Morganti, G., \& Morganti, A. (2011). Transforming nanostructured chitin from crustacean waste into beneficial health products: a must for our society. Nanotechnology, Science and Applications, 4, 123-129. http://dx.doi.org/10.2147/NSA.S22459

Oladimeji, A. A., \& Sadiku, S. O. E. (1991). Mineral constituents of Lates niloticus, Synodontis schall and Sarotherodon galilaeus (Trewaves) from Zaria (Nigeria) dam. Journal of Animal Production Research, 11, 45-52.

Park, B. K., \& Kim, M. (2010). Applications of chitin and its derivatives in biological medicine. International Journal of Molecular Sciences, 11(12), 5152-5164. http://dx.doi.org/10.3390/ijms11125152

Pillay, K. K., \& Nair, N. B. (1973). Observation on the biochemical changes in the gonads and other organs of Uca annulipes, Portunus pelagicus and Metapenaes affinis during reproductive cycles. Marine Biology, 18, 167-198. http://dx.doi.org/10.1007/BF0367985

Radhakrishnan, C. K. (1979). Studies on Portunid crabs of Porto Novo (Crustacea: Decapoda: Brachyura) (Ph.D. thesis). Annamalai University, India.

Ravichandran, S., RameshKumar, G., \& Prince, A. R. (2009). Biochemical composition of shell and flesh of the Indian white shrimp Penaeus indicus (H. milne Edwards 1837). American-Eurasian Journal of Scientific Research, 4(3), 191-194.

Sogbesan, A. O., Olowosegun, T., \& Ibiyo, L. M. O. (2005). Aquaculture potentials and investment opportunity in shrimps and prawns farming in Nigeria. In Proceedings of the 19th Annual Conference of the Fisheries Society of Nigeria (FISON). Ilorin, Nigeria.

Soundarapandian, P., \& Ananthan, G. (2008). Effect of unilateral eyestalk ablation on the biochemical composition of commercially important juveniles of Macrobrachium malcolmsonii. International Journal of Zoological Research, 4(2), 106-112. http://dx.doi.org/10.3923/ijzr.2008.106.112

Sriraman, K. (1978). Biological and biochemical studies on the prawns of portonova coast (Crustacea: Decapoda: Macrura) (Ph.D. thesis). Annamalai University, India.

Stansby, M. E. (1982). Properties of fish oils and their application to handling of fish and to nutritional and industrial use. In R. E. Martin, G. J. Flick, C. E. Hebard, \& D. R. Ward (Eds.), Chemistry and biochemistry of marine food products (pp. 75-95). Westport, C. T.: Avi Publishing Co. 
Subasinghe, S. (1999). Chitin from shell waste-health benefits over-shadowing industrial areas. Info Fish International, 3(99), 58-65.

United States Trade Representative. (2005). African Growth and Opportunity Act Competitiveness Report (pp. 27-29). IV: West African Country Reports. Nigeria.

Wang, X., \& Xing, B. (2007). Importance of structural makeup of biopolymers for organic contaminant sorption. Environmental Science Technology, 41, 3559-3565. http://dx.doi.org/10.1021/es062589t

Willet, W. C. (2007). The role of dietary n-6 fatty acids in the prevention of cardiovascular disease. Journal of Cardiovascular Medicine, 8(Suppl. 1), S42-45. http://dx.doi.org/10.2459/01.JCM.0000289275.72556.13

Zabbey, N., Erondu, E. S., \& Hart, A. I. (2010). Nigeria and the prospect of shrimp farming: critical issues. Livestock Research for Rural Development, 22, 198.

Zhai, X., \& Hawkins, S. J. (2002). Interactions of aquaculture and waste disposal in the coastal zone. Journal of Ocean University of Qingdao, 1, 8-12. 